Regional Review

\title{
A retrospective analysis of the leptospirosis research in Colombia
}

\author{
Andrea Dechner \\ Department of Fisheries and Wildlife, Michigan State University, East Lansing, MI, United States
}

\begin{abstract}
Introduction: Leptospirosis is a re-emerging infectious disease whose prevalence is often underestimated, not only in Colombia, but in most developing countries. The objective of this paper is to assess the research status of leptospirosis in Colombia in order to identify trends, knowledge gaps, and directions for future research.

Methodology: With the aim of gathering all the information available on leptospirosis in the country, a web search was conducted in various indexes and databases. The search terms used were: Leptospirosis + Colombia. A total of 95 publications were found and analyzed using descriptive statistics.

Results: The first report of leptospirosis in the country was published in 1957 . More than $60 \%$ of the published works focus on the prevalence of the disease. The Central part of the country is the area with the highest number of publications. MAT was used in $84 \%$ of the prevalence studies and humans are the most studied taxonomic group, with $45 \%$ of the publications. The highest prevalence of the disease was registered for rodents $(82.7 \%, 62 / 75)$, followed by humans $(67.9 \%, 53 / 78)$, pigs $(67.6 \%, 342 / 506)$, and dogs $(67.2 \%$, 41/61). The prevalence of the disease in the country is associated with occupational factors, hygiene conditions and contact with rodents.

Conclusion: Although leptospirosis is a prevalent disease in Colombia, the limitations of the diagnostic techniques used and the lack of a unified criteria on titers thresholds, make an accurate assessment of the prevalence of the disease in the country problematic.
\end{abstract}

Key words: Leptospirosis; research; Colombia; public health

J Infect Dev Ctries 258-264. doi:10.3855/jidc.3123

(Received 02 November 2012 - Accepted 06 August 2013)

Copyright (C) 2014 Dechner. This is an open-access article distributed under the Creative Commons Attribution License, which permits unrestricted use, distribution, and reproduction in any medium, provided the original work is properly cited.

\section{Introduction}

Leptospirosis is a zoonosis caused by pathogenic bacteria of the genus Leptospira. It has worldwide distribution, although it is more frequent in tropical and subtropical areas. Over the past years, it has been recognized as an emerging disease [1-4], however, its occurrence is often underestimated due to the lack of awareness, non-specific symptomatology, and in many developing countries, to the lack of resources to confirm the diagnosis. It represents not only a public health problem but an economic one, since it causes large economic losses to the livestock industry [5].

Transmission in humans usually occurs through direct or indirect contact with the urine of an infected animal. Although exposure to the disease in humans has been primarily related to occupational factors (animal-associated activities), transmission through contaminated water (either by bathing, drinking, or exposure during flooding) has also been reported [2,68]. The clinical manifestations of the disease vary from mild to extremely severe symptoms and include: jaundice, anorexia, headache, vomiting, abdominal pain, nausea, coughing, diarrhea, and renal failure [9].
There are various methods that can be used to diagnose leptospirosis; however the microscopic agglutination test (MAT) is considered the "gold standard" method. Other methods include: dark field examination, immunofluorescence, culture, Elisa IgM, dot Elisa, and polymerase chain reaction (PCR). The literature on these methods is extensive, and several authors have discussed the advantages and limitations of each method, as well as the discrepancies between the diagnostic results [10-16].

Although an article describing the distribution of the disease in Latin America published in 1960 listed Colombia as a leptospirosis-free country [17], a national publication [18] had previously reported the occurrence of the disease in the country three years before. The first recorded outbreak of the disease in Colombia occurred in 1995, affecting people from poor neighborhoods on the Atlantic coast. This event was associated with exposure to rodents and flooding [8]. Another outbreak was reported among the people of Risaralda in 2006 which resulted in four fatalities [19]. 
The main objective of this paper is to assess the status of the scientific study of leptospirosis in Colombia. To my knowledge, this is the first attempt to gather all the available scientific information on leptospirosis in Colombia with the objective of identifying the trends in research, knowledge gaps, and directions for future research.

\section{Methodology}

During the month of February 2012, a web search with the aim of collecting all published works on leptospirosis in Colombia was conducted, searching the following indexes and databases: ISI Web of Knowledge (all databases), Science Direct, JSTOR and Medline/PubMed. In order to increase the number of results, a search in Google Scholar was also conducted, which includes a variety of databases such as: redalyc, SciELO and LILACS. The search terms used were: Leptospirosis + Colombia. Results used in the analysis only included original research and review articles focusing on leptospirosis that were published in peer reviewed journals. Meeting abstracts, dissertations, theses and technical reports were excluded. Data analysis was done through descriptive statistics. The results are presented according to the diagnostic test used, geographic region and subjects of study.

\section{Results}

Ninety five publications were found (information not shown). The largest number of articles were found in Google scholar $(97.9 \%, 93 / 95)$, followed by ISI web of knowledge $(37.9 \%, 36 / 95)$. Most of the articles $(85.3 \%, 81 / 95)$ are written in Spanish, the official language of the country; while $14.7 \%$ (14/95) are written in other languages.

The first article on leptospirosis in Colombia was published in 1957 [18], and during the following four decades four, six, twelve, and nine articles were published, respectively, with an average of 1.7 articles per year (95 publications in 55 years). There was a marked increase in publications during the first decade of the $21^{\text {st }}$ century, with 50 articles published in ten years. Six and seven articles were published in 2010 and 2011, respectively (Figure 1).

\section{Publications by diagnostic test used}

Most of the articles $(64.2 \%, 61 / 95)$ reported results on the prevalence of the disease and described the diagnostic tests used in detail. MAT was the most frequently used test $(83.6 \%, 51 / 61)$, followed by dark field examination $(13.1 \%, 8 / 61)$, and IgM ELISA and culture (both with $11.5 \%, 7 / 61)$. In 54.1\% (33/61) of these studies only MAT was used, while in $32.8 \%$ $(20 / 61)$ more than one diagnostic test was used (Figure 2).

Publications and prevalence by geographic region studied

Publications specific to a particular region accounted for $76.8 \%$ (73/95). The most studied area in the country is the central area, while the north, east, west and south are still relatively unstudied (Figure 3). The most studied geographic region is Antioquia with $17.8 \%(13 / 73)$ of the publications, followed by Risaralda and Caldas, with 13.7\% (10/73) and 12.3\% $(9 / 73)$, respectively (Figure 3$)$. The highest prevalence of the disease in the country was registered in the coffee zone $(82.7 \%, 62 / 75)$, in the region of Córdoba $(67.9 \%, 53 / 78)$, and in the region of Boyacá $(67.2 \%$, 41/61) (Table 1).

\section{Publications and prevalence by subjects studied}

$87.4 \%(83 / 95)$ of the publications were specific in terms of subjects studied. Humans were the focus of $44.6 \%(37 / 83)$ of the publications, followed by cattle $(27.7 \%, 23 / 83)$, pigs $(16.9 \%, 14 / 83)$, and dogs $(14.5 \%$, 12/83) (Figure 4). The highest prevalence of the disease was registered for rodents $(82.7 \%, 62 / 75)$, followed by humans $(67.9 \%, 53 / 78)$, pigs $(67.6 \%$, $342 / 506)$, and dogs $(67.2 \%, 41 / 61)$ (Table 2).

The serovars reported with the highest frequency in humans were: icterohaemorrhagiae, grippotyphosa, hardjo-prajitno, bratislava, pomona, and bataviae. Those with the highest frequency for cattle were: hardjo, hebdomadis, icterohaemorrhagiae, and wolfii. In the case of pigs the most frequent serovars were: pomona, icterohaemorrhagiae, and bratislava, and in the case of dogs serovars with the highest frequency were: icterohaemorrhagiae, canicola, and grippotyphosa. Common serovars registered for rodents included: grippotyphosa, icterohaemorrhagiae, and bratislava. In the case of horses and goats, the information available is very limited. Although the disease has been studied in few wildlife species in Colombia, the most common serovars cited are: icterohaemorrhagiae, grippotyphosa, copenhageni/ icterohaemorrhagiae and tarassovi. 
Figure 1. Number of publications on leptospirosis in Colombia per year.

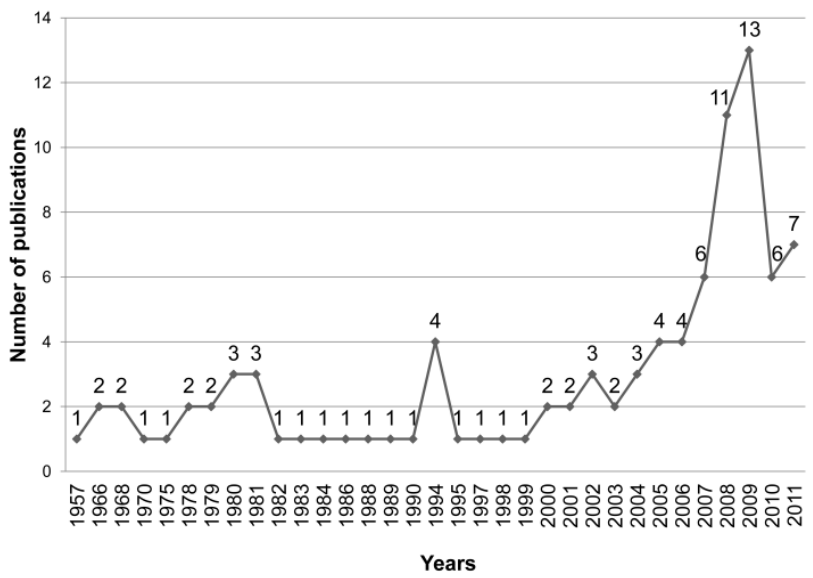

Figure 3. Information availability by geographic region. Eleven studies were excluded from this figure because they were conducted in larger areas and the regions included were not specified, i.e. Magdalena valley, Magdalena medio, south zone, Andean zone, Caribbean zone and Piedemonte zone, each was included in one publication. The western plains zone was included in five publications.

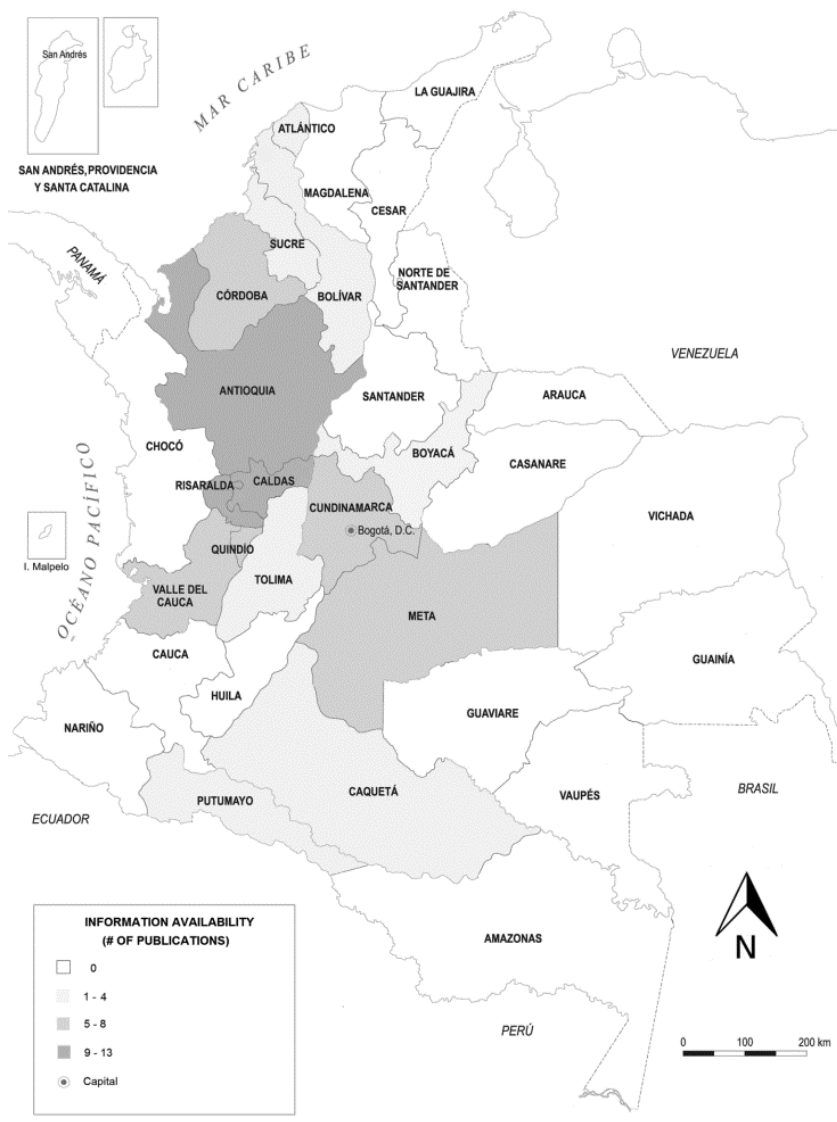

Figure 2. Number of publications by diagnostic technique used. Note that the sum of the results is higher than 61 , this is because in $32.8 \%$ of the publications more than one diagnostic test was used

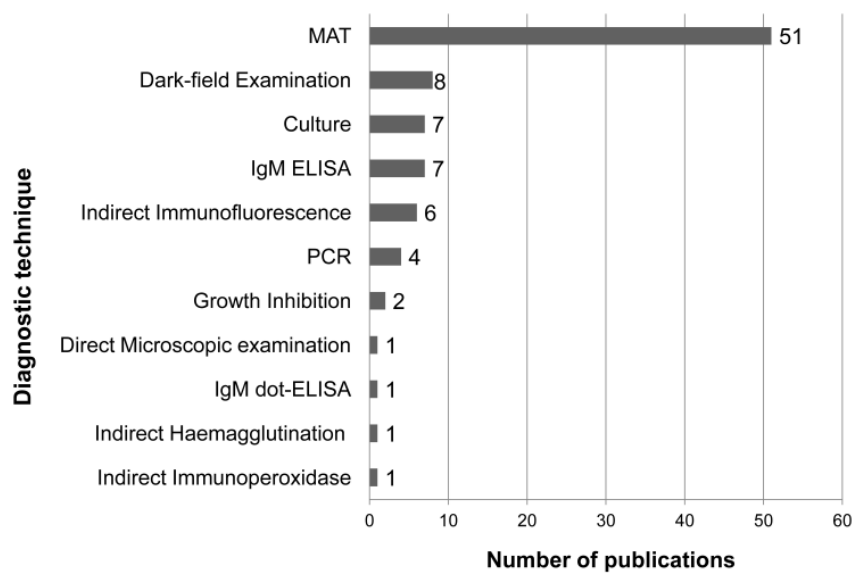

Figure 4. Number of publications by subject of study. Note that the sum of the results is higher than 83 , this is because some publications included more than one group of study subjects

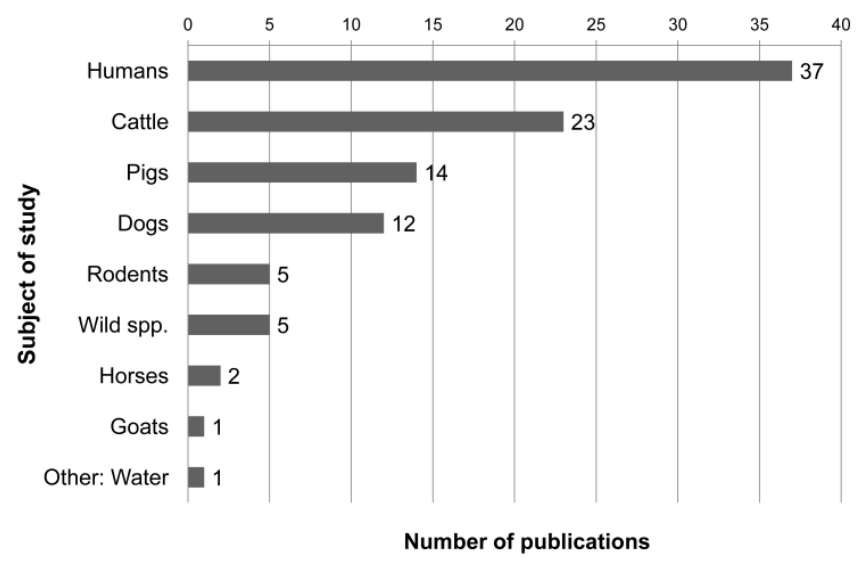


Table 1. Leptospirosis prevalence by geographic region

\begin{tabular}{|c|c|c|c|c|c|}
\hline $\begin{array}{l}\text { Geographic Region with } \\
\text { prevalence data }\end{array}$ & $\begin{array}{c}\text { Prevalence } \\
\text { Range } \\
\left(\min , \text { max }^{*}\right)\end{array}$ & $\begin{array}{l}\text { Sample } \\
\text { Size (n) }\end{array}$ & Subject & Diagnostic Test & Other Observations \\
\hline \multirow{2}{*}{ Antioquia } & $7.4 \%[32]$ & 27 & Primates & $\mathrm{MAT}, \geq 1: 50$ & Primates in captivity \\
\hline & $35.6 \%[22]$ & 642 & Humans & $\mathrm{MAT}, \geq 1: 100$ & Rural area in Necoclí \\
\hline Atlántico & $9.7 \%[33]$ & 970 & Humans & $\mathrm{MAT}, \geq 1: 400$ & \\
\hline \multirow{2}{*}{ Boyacá } & $11 \%[23]$ & 82 & Humans & MAT, $\geq 1: 100$ & \\
\hline & $67.2 \%[34]$ & 61 & Dogs & $\mathrm{MAT}, \geq 1: 100$ & \\
\hline \multirow{2}{*}{$\begin{array}{l}\text { Coffee } \quad \text { zone } \\
\text { Quindío, Risaralda) }\end{array}$} & $0[35]$ & 45 & Humans & MAT, $1: 50$ & $\begin{array}{l}\text { Workers from the Manizales's } \\
\text { Central Slaughterhouse }\end{array}$ \\
\hline & $82.7 \%[36]$ & 75 & Rodents & Dark field examination \& culture & Swine farms \\
\hline \multirow{2}{*}{ Córdoba } & $12 \%[37]$ & 200 & Dogs & $\mathrm{MAT}, \geq 1: 100$ & \\
\hline & $67.9 \%[24]$ & 78 & Humans & $\mathrm{MAT}, \geq 1: 100$ & \\
\hline \multirow{2}{*}{ Cundinamarca } & $31 \%[38]$ & 200 & Pigs & Indirect immunoperoxidase & \\
\hline & $52.2 \%[39]$ & 46 & Bulls & MAT, $\geq 1: 25$ & \\
\hline \multirow[t]{2}{*}{ Meta** } & $0[41]$ & $\geq 56$ & Wild animals & $\begin{array}{l}\text { MAT, non-mentioned cut-off, } \\
\text { culture }\end{array}$ & 56 species of wild animals \\
\hline & $48 \%[42,25]$ & 27 & Humans & ELISA & Fish farm workers. \\
\hline South zone & $18.4 \%[43]$ & 353 & Humans & $\mathrm{MAT}, \geq 1: 100$ & \\
\hline Sucre & $13.3 \%[44]$ & 90 & Humans & ELISA & \\
\hline \multirow{2}{*}{ Tolima*** } & $6 \%[46]$ & 850 & Humans & $\mathrm{MAT}, \geq 1: 100$ & \\
\hline & $21.4 \%[46]$ & 850 & Dogs & $\mathrm{MAT}, \geq 1: 100$ & \\
\hline \multirow{2}{*}{ Valle del Cauca } & $20.6 \%[47]$ & 150 & Humans & $\mathrm{MAT}, \geq 1: 800$ & \\
\hline & $41.1 \%[48]$ & 197 & Dogs & $\mathrm{MAT}, \geq 1: 100$ & \\
\hline
\end{tabular}

Table 2. Leptospirosis prevalence by subject of study

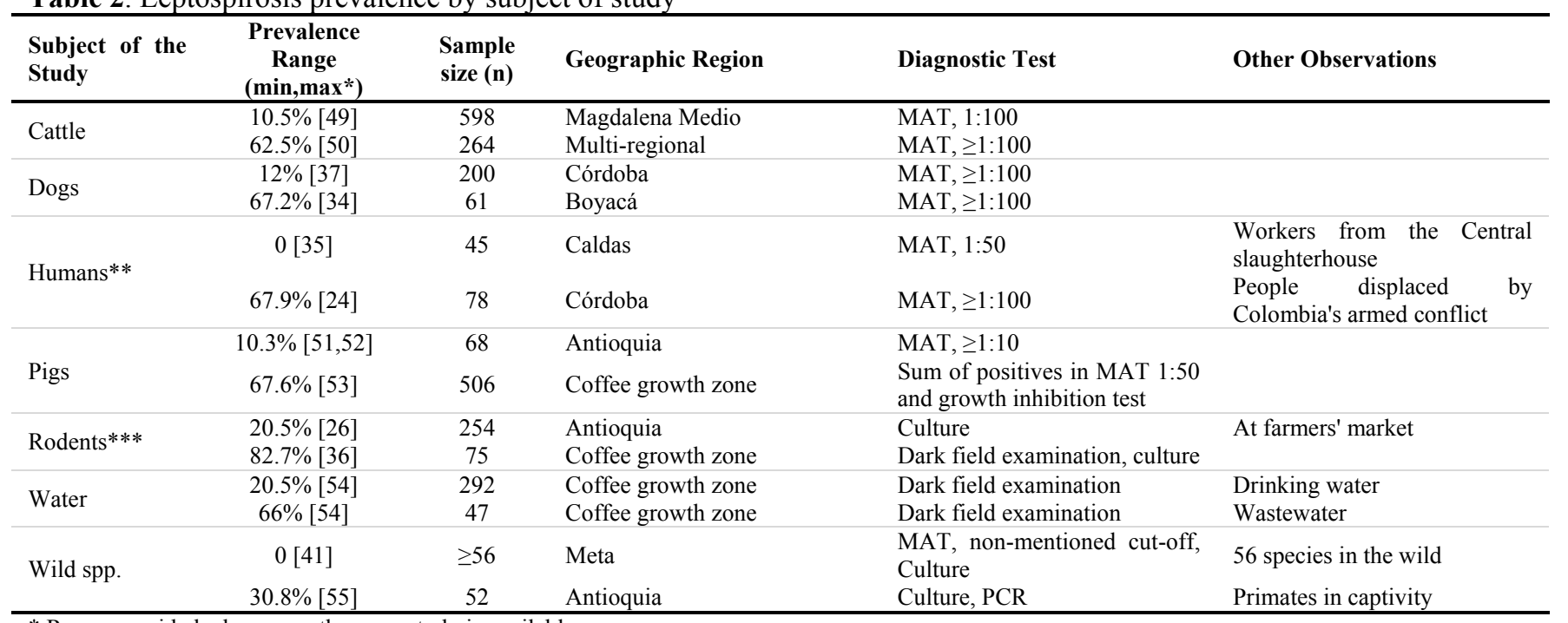

* Range provided when more than one study is available

** Excluding a breakout reported in the geographic region of Risaralda in 2006 [19] and a report of $100 \%$ prevalence in a study with a sample size of five individuals [40].

*** A study reported a 100 prevalence in this taxonomic group [40], however, it was excluded from the range due to the low sample size (n $=15$ ) and therefore the low representativity. 


\section{Discussion}

Although the first work on leptospirosis in the country was published 56 years ago, it was not until the first decade of the $21^{\text {st }}$ century that the research reached its highest point. It is important to note that the publication rate found may be underestimated due to the fact that some national journals may still not be indexed. Although the overall prevalence of the disease is widespread in the country, results vary greatly among areas and among organisms.

MAT was the most frequently used diagnostic test but there is a lack of unified criteria for determining positive MAT titers/cut off points. Interpretations of the MAT are difficult due to the fact that agglutinating antibodies remain for long periods of time in the body after infection. Also, there is an ongoing debate about when a leptospira agglutination titer is positive and significant (cut-off); some consider a titer to be positive at 1:100 while others consider it to be positive at higher values. According to the US Center for Disease Control and Prevention [20], a titer of $\geq 1: 200$ (in combination with clinical symptoms) is used to define a probable case, however, in places where the prevalence of the disease is common, as in the case of most tropical countries, a titer of 1:200 may not have a diagnostic value and a higher cut-off value is necessary [2].

Since, due to previous infections, antibodies may be more persistent in areas with higher prevalence of the disease, the cut-off should be specific to the region in question [21]. It is recommended that the serological results should be analyzed considering specific regional characteristics (such as prevalence of the disease, risks of exposure, etc.). In addition, it is recommended to analyze two consecutive serum samples in order to identify a significant, four-fold or greater increase in titers [21].

Based on the results reported for Colombia and considering: 1) that more than $80 \%$ of the studies on the prevalence of the disease were based on the MAT, 2) the difficulties of interpreting the MAT and low titers, and 3) the doubtful results on the efficacy of diagnostic tests, including the MAT [11-15], it can be concluded that the real prevalence of the disease in the country is still unknown and that there is a need to continue to search for methods that can accurately assess its prevalence. Work at molecular level is revealing interesting results in various parts of the world and should be considered in future works [1016].

There is still no information on the prevalence of the disease in several of the 32 geographic regions, and with exception for the central area, most of the country is still relatively unstudied. There is a need to expand the geographical scope of the research, giving priority to regions with the highest prevalence of leptospirosis where actions to control and reduce the disease are most urgent.

Humans are the most studied taxonomic group. Factors associated with the prevalence of the disease, as established through research, include: occupational factors, hygiene conditions, frequent contact with rodents, and owning/working with animals, all of which considerably increase the risks of contagion [22-26]. Medical treatment depends on the severity of the symptoms. Severe leptospirosis may be treated with intravenous penicillin, less severe cases may be treated with antibiotics such as amoxycillin, ampicillin, doxycycline or erythromycin. Ceftriaxone also appears to be effective [27]. On the other hand, results from a review assessing seven clinical trials that tested antibiotics to treat leptospirosis showed that the benefit of antibiotic therapy remains unclear, particularly for severe cases [28]. Although the use of antibiotics is controversial, the World Health Organization [21] recommends that treatment be initiated with antibiotics as soon as leptospirosis is suspected.

The prevalence of serovars among the different taxonomic groups is consistent with what has been reported in the literature [2,29]. The few studies done on wild animals in Colombia, reported a low prevalence of the disease. Small mammals like opossums and rodents are more frequent carrier hosts of leptospira than are larger mammals. Similar results were reported in Peru [30], where leptospira was found to be frequent in small mammals like bats, rodents and marsupials. In Brazil, studies on tapirs (Tapirus terrestris) have shown negative results for Leptospira spp. (0/10) [31].

Finally, future work in Colombia should provide information not only on the prevalence of the disease, but on other topics such as the effectiveness of the diagnostic tests, factors associated to the occurrence of the disease, as well as on the environmental, social and political strategies necessary to reduce the prevalence of the disease in the country.

\section{Acknowledgements}

I would like to thank Dr. Kevin M. Flesher and the anonymous reviewers for their valuable comments on the manuscript. 


\section{References}

1. Brandling-Bennett AD, Pinheiro F (1996) Infectious diseases in Latin America and the Caribbean: are they really emerging and increasing? Emerg Infect Dis 2: 59-61.

2. Levett P (2001) Leptospirosis. Clin Microbiol Rev 14: 296326.

3. Langston CE, Heuter KJ (2003) Leptospirosis, A re-emerging zoonotic disease. Vet Clin Small Anim 33: 791-807.

4. Bharti AR, Nally JE, Ricaldi JN, Matthias MA, Diaz MM, Lovett MA, Levett PN, Gilman RH, Willig MR, Gotuzzo E, Vinetz JM (2003) Leptospirosis: a zoonotic disease of global importance. Lancet Infect Dis 3: 757-771.

5. Ellis WA (1984) Bovine leptospirosis in the tropics: Prevalence, pathogenesis and control. Preventive Vet Med 2: 411-421.

6. Ricaldi JN, Vinetz JM (2006) Leptospirosis in the tropics and in travelers. Curr Infect Dis Rep 8: 51-58

7. Monahan AM, Miller IS, Nally JE (2009) Leptospirosis: risks during recreational activities. J Appl Microbiol 107: 707-716

8. Epsein PR, Cáliz PO, Blanco RJ (1995) Climate and disease in Colombia. The Lancet 346: 1243-1244.

9. Vijayachari P, Sugunan AP, Shriram AN (2008) Leptospirosis: an emerging global public health problem. J Biosci 33: 557-569.

10. Levett PN, Edwards CN (2009) Leptospirosis. In: Brachman PS, Abrutyn E, editors. Bacterial infections of humans. New York: Springer 439-460.

11. Cumberland P, Everard CO, Levett PN (1999) Assessment of the efficacy of an IgM-elisa and microscopic agglutination test (MAT) in the diagnosis of acute leptospirosis. Am J Trop Med Hyg 61: 731-734

12. Bajani MD, Ashford DA, Bragg SL, Woods CW, Aye T, Spiegel RA, Plikaytis BD, Perkins BA, Phelan M, Levett PN, Weyant RS (2003) Evaluation of four commercially available rapid serologic tests for diagnosis of leptospirosis. J Clin Microbiol 41: 803-809

13. Smythe LD, Wuthiekanun V, Chierakul W, Suputtamongkol Y, Tiengrim S, Dohnt MF, Symonds ML, Slack AT, Apiwattanaporn A, Chueasuwanchai S, Day NP, Peacock SJ (2009) The Microscopic Agglutination Test (MAT) Is an Unreliable Predictor of Infecting Leptospira Serovar in Thailand. Am J Trop Med Hyg 81: 695-697

14. Hernández-Rodríguez P, Díaz CA, Dalmau EA, Quintero GM (2011). A comparison between polymerase chain reaction (PCR) and traditional techniques for the diagnosis of leptospirosis in bovines. J Microbiol Methods 84: 1-7

15. Limmathurotsakul D, Turner EL, Wuthiekanun V, Thaipadungpanit J, Suputtamongkol Y, Chierakul W, Smythe LD, Day NP, Cooper B, Peacock SJ (2012) Fool's Gold: Why Imperfect Reference Tests Are Undermining the Evaluation of Novel Diagnostics: A Reevaluation of 5 Diagnostic Tests for Leptospirosis. Clin Infect Dis 55: 322-331

16. Schreier S, Doungchawee G, Chadsuthi S, Triampo D, Triampo W (2013) Leptospirosis: current situation and trends of specific laboratory tests. Exp Rev Clin Imm 9: 263-280

17. Alexander AD (1960) The distribution of leptospirosis in Latin America. Bull World Health Organ 23: 113-125

18. Muñoz-Rivas G (1957) Existe la leptospirosis en Colombia. Rev Fac Med Vet Zootec 21: 590-594

19. Segura O, Heredia D, Saad C (2008) Brote de leptospirosis humana en Risaralda Colombia, junio de 2006. Inf Quinc Epidemiol Nac 13: 239-254
20. Center for Disease Control and Prevention (1997) Case definitions for infectious conditions under public health surveillance. MMWR Recom Rep 46: 1-55

21. World health Organization. 2003; Human leptospirosis: guidance for diagnosis, surveillance and control. Available: http://whqlibdoc.who.int/hq/2003/WHO_CDS_CSR_EPH_20 02.23.pdf. Accessed: 25 July 2013.

22. Padmanabha $\mathrm{H}$, Hidalgo $\mathrm{M}$, Valbuena $\mathrm{G}$, Castaneda $\mathrm{E}$, Galeano A, Puerta H, Cantillo C, Mantilla G (2009) Geographic Variation in Risk Factors for SFG Rickettsial and Leptospiral Exposure in Colombia. Vector Borne and Zoonotic Dis 9: 483-490

23. Hernández Niño J, Hernández Molano A, Tello Castro V (2009) Seroprevalencia de leptospirosis en perros callejeros y personas de alto riesgo ocupacional en la ciudad de Tunja. Teoría y praxis investigativa 4: 33-38

24. Rodríguez Barreto H, Lozano Montoya C, Bedoya Sánchez C, Grondona Paternina L (2009). Prevalencia de leptospirosis en humanos en la zona urbana del municipio de Puerto Libertador, Córdoba, Colombia. Rev de Investigación Agraria y Ambiental, RIAA 1: 23-28.

25. Díaz PL, Zapata I, Góngora A, Parra J, Aponte GL, Gómez LL (2008) Detección de anticuerpos IgM a Leptospira en humanos en riesgo ocupacional en Villavicencio, Meta. Rev MVZ Córdoba 13: 1120-1127

26. Agudelo-Flórez $\mathrm{P}$, Londoño $\mathrm{AF}$, Quiroz VH, Ángel JC, Moreno N, Loaiza ET, Muñoz LF, Rodas JD (2009) Prevalence of Leptospira spp. in urban rodents from a groceries trade center of Medellin, Colombia. Am J Trop Med Hyg 81: 906-910

27. Panaphut $\mathrm{T}$, Domrongkitchaiporn S, Vibhagool A, Thinkamrop B, Susaengrat W (2003) Ceftriaxone compared with sodium penicillin $\mathrm{g}$ for treatment of severe leptospirosis. Clin Infect Dis 36: 1507-13

28. Brett-Major DM, Coldren R (2012) Antibiotics for leptospirosis. Cochrane Database of Systematic Reviews 15; 2:CD008264

29. Ellis WA (1986) Leptospirosis. J Small Anim Pract 27: 683692

30. Bunnell JE, Hice CL, Watts DM, Montrueil V, Tesh RB, Vinetz JM (2000) Detection of pathogenic Leptospira spp. infections among mammals captured in the Peruvian Amazon Basin region. Am J Trop Med Hyg 63: 225-228

31. Furtado MA, Jácomo ATA, Kashivakura CK, Tôrres NM, Marvulo MFV, Ragozo AMA, Souza SLP, Neto JSF, Vasconcellos SA, Morais ZM, Cortez A, Richtzenhain LJ, Silva JCR, Silveira L (2010) Serologic survey for selected infectious diseases in free-ranging Brazilian tapirs (Tapirus terrestris) in the Cerrado of central Brazil. J Zoo Wild Med 41: 133-136.

32. Jiménez-Nicholls L, Perez J, Loaiza J, Ocampo M, AgudeloFlórez P (2009) Determinación de la frecuencia de leptospirosis en felinos y primates del Parque Zoológico Santa Fe, Medellin, Colombia. Rev CES MVZ 4: 39-47

33. Macías-Herrera JC, Vergara C, Romero C, Falconar AKI (2005) Comportamiento de la leptospirosis en el departamento de Atlántico (Colombia). Enero de 1999 a marzo del 2004. Salud Uninorte 20:18-29

34. Bermúdez CS, Pulido MM, Andrade BR (2010) Seroprevalencia de Leptospira spp. en caninos y humanos de tres barrios de Tunja, Colombia. Rev MVZ Córdoba 15: 2185-2193 
35. Orrego Uribe A, Giraldo De Leon G, Rios Arango B, Valencia Prada PA (2003) Leptospirosis en personas de riesgo de quince explotaciones porcinas y de la central de sacrificio de Manizales, Colombia. Arch Med Vet 35: 205213

36. Giraldo De León G, Orrego Uribe A, Betancurth AM (2002) Los roedores como reservorios de Leptospiras en planteles porcinos de la zona central cafetera de Colombia. Arch Med Vet 34: 69-78

37. Sánchez - García AE, Ballut Pestana JC, Calderón - Rangel, A; Rodríguez - Rodríguez VC (2010) Leptospirosis: Enfermedad Endémica en Caninos de Áreas Rurales de Montería (Córdoba). Orinoquia 14: 160-167

38. Romero D, Díaz H, Serna A, Orjuela JJ, Gallego Marín MI, Mogollón Galvis JD (1994) Detección de la leptospirosis renal porcina (LRP) mediante la técnica de inmuno peroxidasa (IP) Rev ICA 29:181-191

39. Villalobos R, Rozo J, Gallego Marín MI, Sedano de León L, López de Herrera AI (1986). Evaluación sanitaria en toros de fomento del Departamento de Cundinamarca. I. Estudios Bacteriológicos. Rev Acovez 10: 7-17

40. Morales-Cabezas RJ, Bravo-Tamayo D, Moreno-Velasquez D, Góngora A, Ocampo A (2007) Asociación serológica de la infección por leptospira en humanos, porcinos y roedores en una granja de Villavicencio-Colombia. Orinoquia 11: 73-80

41. Wells EA, D'Alessandro A, Morales GA, Angel D (1981) Mammalian wildlife diseases as hazards to man and livestock in an area of the Llanos Orientales of Colombia. J Wildlife Dis 17: $153-162$

42. Góngora A, Parra J, Aponte L, Gómez L (2008) Seroprevalencia de Leptospira spp. en grupos de población de Villavicencio, Colombia. Rev Salud pública 10: 269-278

43. Sebek Z, Sixl W, Valova M, Marth E, Köck M, Reinthaler F (1989) Serological investigations for leptospirosis in humans in Columbia. Geogr Med Suppl 3: 51-60

44. Ríos R, Franco S, Mattar S, Urrea M, Tique V (2008) Seroprevalencia de Leptospira sp., Rickettsia sp. y Ehrlichia sp. en trabajadores rurales del departamento de Sucre, Colombia. Infectio 12: 319-323

45. Buriticá Gaviria EF, Echeverry Bonilla DF, Cruz Sarmiento LJ (2008) Leptospirosis en el departamento del Tolima, Colombia. Rev CES MVZ 3: 42-47

46. Romero MH, Sánchez JA, Hayek LC (2010) Prevalencia de anticuerpos contra Leptospira en población urbana humana y canina del Departamento del Tolima. Rev salud pública 12: 268-275

47. Astudillo Hernández M, González Rodríguez A, Batista Santiesteban N, Mirabal Sosa M, Menéndez Hernández J (2009) Estudio seroepidemiológico de la leptospirosis humana en el departamento del Valle del Cauca, Colombia. Rev Cubana Med Trop 61: 1-10

48. Rodríguez AL, Ferro BE, Varona MX, Santafé M (2004) Evidencia de exposición a Leptospira en perros callejeros de Cali. Biomédica 24: 291-295

49. Orrego Uribe A, Hurtado G, Castellanos D (1990) Prevalencia de varias entidades patológicas en bovinos del Magdalena Medio (Colombia). Rev ICA 25: 185-191

50. Volina EG, Al'sate LE, Levina LF (1999) The etiological structure of leptospirosis in agricultural animals in Colombia. Zh Mikrobiol Epidem Immunobiol 3: 80-81

51. Ochoa JE, Sánchez A, Ruiz I (2000) Epidemiología de la leptospirosis en una zona andina de producción pecuaria. Rev Panam Salud Pública 7: 325-331

52. Ochoa JE, Sánchez A, Ruiz I (2001) Epidemiología de la leptospirosis en una zona andina de producción pecuaria. Infectio 5: 96-105

53. Orrego Uribe A, Giraldo de León G, Bohórquez Ríos A, Escobar Macias J, Quinceno Arias J, Ríos B, Santafé M, Hurtado JE (2001) Aproximación a la prevalencia serológica real de la leptospirosis en porcinos-cría. Rev Corpoica 3: 1116

54. Giraldo De León G, Orrego Uribe A, Santacruz M, Yepes E. Leptospirosis (2002) Las aguas de la explotación porcina como vehículo de la Leptospira, en la zona central cafetera de Colombia. Arch Med Vet 34: 79-87

55. Szonyi B, Agudelo-Flórez P, Ramírez M, Moreno N, Ko AI (2011) An outbreak of severe leptospirosis in capuchin (Cebus) monkeys. Vet J 188: 237-239

\section{Corresponding author}

Andrea Dechner

Department of Fisheries and Wildlife,

20 Natural Resources building.

Michigan State University, East Lansing, MI. USA.

Tel.: +1 5174813539 .

E-mail: dechners@msu.edu.

Conflict of interests: No conflict of interests is declared. 